\title{
Established populations of the indoor silverfish Lepisma saccharinum (Insecta: Zygentoma) in red wood ant nests
}

\author{
Ruben Claus ${ }^{1}$, Pieter Vantieghem ${ }^{1}$, Rafael Molero-Baltanás ${ }^{2} \&$ \\ Thomas Parmentier ${ }^{1,3, * \odot}$ \\ ${ }^{1}$ Terrestrial Ecology Unit (TEREC), Department of Biology, Ghent University, \\ K.L. Ledeganckstraat 35, B-9000 Gent, Belgium. \\ ${ }^{2}$ Depto. de Zoología, University of Córdoba, E-14071 Córdoba, Spain. \\ ${ }^{3}$ Research Unit of Environmental and Evolutionary Biology, Namur Institute of Complex Systems, \\ and Institute of Life, Earth, and the Environment, University of Namur, Rue de Bruxelles 61, \\ 5000 Namur, Belgium. \\ *Corresponding author: thomas_parmentier@msn.com
}

Keywords. Commensalism, myrmecophile, pest species, red wood ants, thermophilous.

Claus R., Vantieghem P., Molero-Baltanás R. \& Parmentier T. (2022). Established populations of the indoor silverfish Lepisma saccharinum (Insecta: Zygentoma) in red wood ant nests. Belgian Journal of Zoology 152: 45-53. https://doi.org/10.26496/bjz.2022.98

This paper presents the records of stable outdoor populations of the silverfish Lepisma saccharinum (Zygentoma: Lepismatidae) in red wood ant nests in Belgium. This hostile nest environment is a surprising niche, as this silverfish species is usually found indoors and strictly bound to humans in North-Western Europe.

Ant nests are rich micro-environments that attract a diverse array of arthropods [1]. This is partly because temperature and moisture of ant nests are often regulated, providing optimal conditions for its tenants throughout the year $[2,3]$. An especially rich community of ant associates can be found in the organic mound nests of red wood ants (Formica rufa group) [4,5]. These ants perfected thermoregulation in their mound nests $[2,6]$. They can keep the inner nest temperature higher than the ambient temperature from early spring to late autumn [6]. The organic mounds of red wood ants also provide a favorable humid environment buffered against drought [7].

Silverfish (Insecta: Zygentoma) are a primitive group of wingless insects of which different lineages associate with ants $[5,8,9]$. Some have evolved to obligate symbionts and can only be found in ant nests, whereas others engage in a facultative association and occur with and without ants [8]. Some silverfish are known to steal retrieved prey from their host ants or to beg for liquid food droplets [1,9], but commensalism is widespread as well [8]. Six silverfish species have been reported in Belgium so far: five synanthropic species that are found indoors (Ctenolepisma longicaudatum, Ctenolepisma lineatum, Thermobia domestica, Nicoletia phytophila and Lepisma saccharinum) [10,11] and one species 
(Atelura formicaria) which lives outdoors in strict association with ants [12]. Lepisma saccharinum Linnaeus, 1758 is a cosmopolitan silverfish that feeds on materials rich in starch and cellulose. It is frequently found indoors in humid places, such as attics, bathrooms, and basements and can become a pest species. In warmer regions, such as in the Mediterranean area, it can also occur outdoors under stones and in leaf litter. In Spain, L. saccharinum has also been recorded in nests of different ant species of the genera Lasius, Aphaenogaster, Messor, Tapinoma and Tetramorium. An overview of the habitats of $L$. saccharinum reported in the literature is given in Table 1. Crucially, L. saccharinum is typically bound to urban settings in temperate Europe, and only a few individuals were reported outside buildings so far ([10], Table 1). Mendes [13] revised every citation of L. saccharinum known up to that date and wrote that, "with the exception of the Mediterranean subregion", this species "seems exclusively synanthropic, except for rare cases of colonizing natural habitats."

In the framework of a detailed monitoring campaign of arthropods associated with red wood ants (Formica rufa Linnaeus, 1761 and Formica polyctena Förster, 1850), we found over a three-year period (2018-2021) large numbers of $L$. saccharinum in and at the periphery of these ants' nests (Fig. 1). The identification of $L$. saccharinum was verified by checking the redescription of Mendes [14]. The absence of a setal collar on the pronotum, the types of specialized antennal sensilla and the type of paramera place it within the subfamily Lepismatinae. The urotergal chaetotaxy, the type of notal trichobothrial areas (all anterior open and all posterior closed) and the hyperdeveloped paramera are diagnostic characters of the genus Lepisma [15]. Lepisma saccharinum has a characteristic combination of characters (pigmentation, structure of infralateral groups of setae of urotergites, shape of the tenth urotergite, length and number of divisions of the ovipositor, etc.) that distinguishes it from other species of the genus $[15,16]$.

We used plastic boxes (Sunware Q-Line Box: $27 \times 8.4 \times 9 \mathrm{~cm}$, volume: $1.3 \mathrm{~L}$ ) with a $1 \mathrm{~cm}$ layer of moist plaster on the bottom as traps to collect the silverfish. The sides of these traps were too slippery for the silverfish to escape from, but ants could easily climb out of these boxes. The traps at the periphery of the nest were buried so that their top rim was level with the soil surface. We covered these traps with a plastic roof to prevent rain falling into them. The roof was positioned $2 \mathrm{~cm}$ above the opening of the traps by attaching plastic caps in the corners of the roof (details and pictures see [17]). Traps were left for one week and then emptied. We used the same type of traps with roofs to assess the diversity in the nests. These traps were completely buried in the organic mound of the nest. As ants gradually filled the
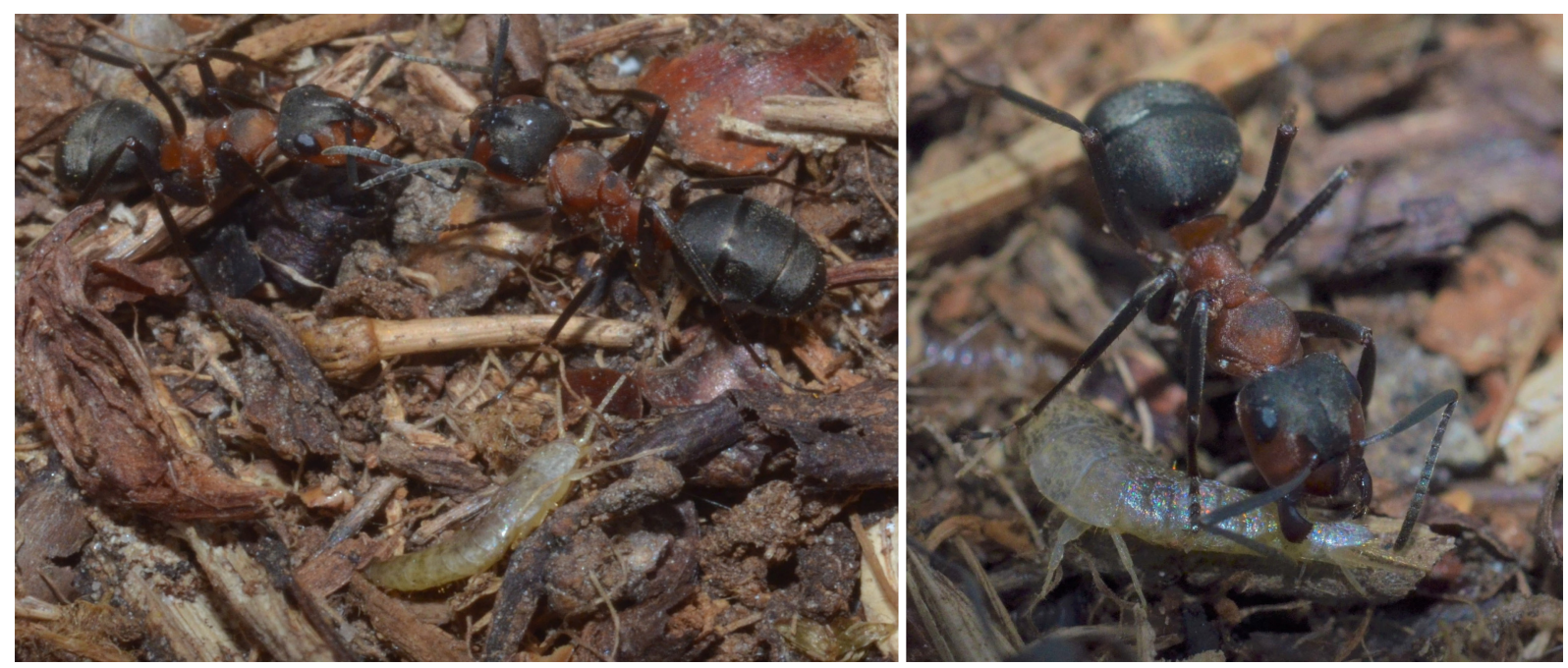

Figure 1 - Interaction between Formica rufa (red wood ants) and Lepisma saccharinum in the organic mound nest. The worker in the right figure tries to grab the agile silverfish. 


\section{TABLE 1}

Habitats of Lepisma saccharinum according to literature on Lepismatidae. Only certain identifications have been included $(*)$. Abbreviations: $\mathrm{A}=$ with ants; $\mathrm{S}=$ synanthropic; $\mathrm{F}=$ free-living (in natural habitats; $\mathrm{N}=$ no data. When the number of citations given in a work for a certain habitat is not mentioned, the occurrence of the species is indicated only with an X.

\begin{tabular}{|c|c|c|c|c|c|c|}
\hline \multirow[t]{2}{*}{ Author (s) and year of publication } & \multirow[t]{2}{*}{ reference } & \multirow[t]{2}{*}{ Geographic location } & \multicolumn{4}{|c|}{ Habitat } \\
\hline & & & $\mathbf{A}$ & $\mathbf{S}$ & $\mathbf{F}$ & $\mathbf{N}$ \\
\hline SMITH (2015) & {$[16]$} & Australia & & 1 & & 6 \\
\hline Molero-BALTANÁs et al. (2014) & [21] & Spain & 6 & 20 & 66 & \\
\hline LOCK (2007) & {$[10]$} & Belgium & & $\mathrm{X}$ & 2 & \\
\hline BLOCH (2007) & {$[22]$} & Faroe Islands & & $\mathrm{X}$ & & \\
\hline MENDES (2002) & [23] & Portugal & & 6 & 7 & \\
\hline MOLERO-BALTANÁS et al. (2000) & [24] & Italy (Sicily) & & & 1 & \\
\hline MENDES et al. (2000) & {$[25]$} & Azores Islands & & 6 & & 2 \\
\hline HAZRA et al. (1999) & [26] & India & & 2 & & 1 \\
\hline MOLERO-BALTANÁS et al. (1996) & [27] & Spain & & 29 & 76 & \\
\hline MENDES (1995) & [28] & Israel & & & & 1 \\
\hline MOLERO-BALTANÁS et al. (1994) & [29] & Spain & & & 7 & \\
\hline MENDES et al. (1992) & {$[30]$} & Canary Islands & & 1 & & \\
\hline MENDES (1992) & [31] & Algeria, Tunisia & & & 2 & \\
\hline MENDES (1992) & [31] & Canada (British Columbia) & & 1 & & \\
\hline MENDES (1989) & {$[32]$} & China & & & & 1 \\
\hline MENDES (1985) & [33] & Poland & & 4 & & \\
\hline MENDES (1984) & [34] & Greece (Santorini Island) & & & & 2 \\
\hline MENDES (1983) & {$[35]$} & Cape Verde Islands & & & & 1 \\
\hline MENDES (1981) & [36] & N Macedonia, Turkey & & & 4 & \\
\hline MENDES (1980a) & {$[37]$} & Germany, France & & 3 & & \\
\hline MENDES (1980a) & [37] & Corse, Spain & & & 2 & \\
\hline MENDES (1980a) & [37] & England, Algeria & & & & 2 \\
\hline MENDES (1980a) & [37] & Portugal & 3 & 15 & 32 & \\
\hline MENDES (1980b) & [38] & Malta & & & & 1 \\
\hline MENDES (1980c) & [39] & Italy & & & 4 & \\
\hline WYGODZINSKY (1970) & [40] & Saint Helena island & & $\mathrm{X}$ & $\mathrm{X}$ & \\
\hline WYGODZINSKY (1967) & [41] & Brazil, Bolivia, Argentina & & & & $\mathrm{X}$ \\
\hline PACLT (1966) & {$[42]$} & Panama, Colombia & & & & 2 \\
\hline WYGODZINSKY (1962) & [43] & Afghanistan & & 1 & & \\
\hline PACLT (1961) & [44] & Austria, France & & & & 2 \\
\hline PACLT (1961) & [44] & Germany & 1 & 2 & & \\
\hline WYGODZINSKY (1959) & {$[45]$} & St Martin Island (Lesser Antilles) & & & 1 & \\
\hline WYGODZINSKY (1958) & [46] & France & & & 2 & \\
\hline WYGODZINSKY (1954) & [47] & Netherlands & & 10 & 1 & \\
\hline UCHIDA (1954) & [48] & Japan & & 1 & & \\
\hline WYGODZINSKY (1952) & [49] & Cyprus & & & & 1 \\
\hline SWEETMAN (1944) & {$[50]$} & United States & & $\mathrm{X}$ & & \\
\hline AGRELL (1944) & [51] & Sweden & & $\mathrm{X}$ & & \\
\hline
\end{tabular}




\begin{tabular}{|c|c|c|c|c|c|c|}
\hline \multirow[t]{2}{*}{ Author (s) and year of publication } & \multirow[t]{2}{*}{ reference } & \multirow[t]{2}{*}{ Geographic location } & \multicolumn{4}{|c|}{ Habitat } \\
\hline & & & $\mathbf{A}$ & $\mathbf{S}$ & $\mathbf{F}$ & $\mathbf{N}$ \\
\hline WYGODZINSKY (1941) & [52] & France & & & 1 & \\
\hline WYGODZINSKY(1941) & [52] & Germany & & 1 & & \\
\hline WYGODZINSKY (1941) & {$[52]$} & Switzerland & & 4 & 3 & \\
\hline STACH (1930) & [53] & Spain & & & 1 & \\
\hline STACH (1929) & [54] & Hungary & & 6 & & \\
\hline TILLYARD (1924) & {$[55]$} & New Zealand & & $X$ & & \\
\hline LINNANIEMI (1912) & {$[56]$} & Finland & & 4 & & \\
\hline OUDEMANS (1895) & [57] & Netherlands & & $X$ & & \\
\hline UZEL (1891) & [58] & Czech Republic & & $\mathrm{X}$ & & \\
\hline PARONA (1882) & [59] & Italy & & 1 & & 2 \\
\hline BECKE (1866) & {$[60]$} & Ukraine & & & & $\mathrm{X}$ \\
\hline CONTARINI (1845) & [61] & Italy (Padova, Venecia) & & $\mathrm{X}$ & & \\
\hline MOHR (1786) & {$[62]$} & Denmark & & $X$ & & \\
\hline FÜSSLY (1775) & [63] & Switzerland & & $\mathrm{X}$ & & \\
\hline GEOFFROY (1762) & [64] & France (Paris) & & $\mathrm{X}$ & & \\
\hline LINNAEUS (1758) & [65] & America & & $\mathrm{X}$ & & \\
\hline
\end{tabular}

* Most of these reports correspond to works authored by Zygentoma specialists, since a lot of mistakes have been detected in the literature, especially misidentifications related to the confusion of Ctenolepisma species with Lepisma saccharinum. Those reports where there is evidence or reasonable suspect for incorrect identifications have been discarded.

TABLE 2

Overview of the sampled nests and number of trapped L. saccharinum silverfish. Nest size (nest surface), coordinates and sampling period are given.

\begin{tabular}{|c|c|c|c|c|c|c|c|}
\hline \multirow[t]{2}{*}{ Nest } & \multirow{2}{*}{$\begin{array}{c}\text { Nest } \\
\text { surface } \\
\left(\mathbf{m}^{2}\right)\end{array}$} & \multirow[t]{2}{*}{ Coordinates } & \multirow[t]{2}{*}{ Period } & \multicolumn{2}{|c|}{ Inside nest } & \multicolumn{2}{|c|}{ Periphery nest } \\
\hline & & & & Traps $(\mathbf{N})$ & Silverfish (N) & Traps $(\mathbf{N})$ & Silverfish (N) \\
\hline \multicolumn{8}{|c|}{ Site: Poperinge } \\
\hline A & 0.38 & $50.885661^{\circ} \mathrm{N}, 2.698817^{\circ} \mathrm{W}$ & 6-13 June 2018 & 1 & 1 & 1 & 2 \\
\hline A & & & 20-27 June 2018 & 1 & 3 & 1 & 3 \\
\hline A & & & 14-21 July 2018 & 1 & 1 & 1 & 6 \\
\hline A & & & 1-8 Aug. 2018 & 1 & 0 & 1 & 12 \\
\hline A & & & 15-22 Sep. 2018 & 1 & 0 & 1 & 28 \\
\hline A & & & 3-10 Aug. 2020 & 3 & 186 & & \\
\hline A & & & 10-17 Aug. 2021 & 3 & 68 & & \\
\hline B & 0.05 & $50.884457^{\circ} \mathrm{N}, 2.693178^{\circ} \mathrm{W}$ & 3-10 Aug. 2020 & & & 3 & 4 \\
\hline $\mathrm{C}$ & 0.20 & $50.884939^{\circ} \mathrm{N}, 2.695236^{\circ} \mathrm{W}$ & 3-10 Aug. 2020 & & & 3 & 1 \\
\hline $\mathrm{D}$ & 0.35 & $50.885369^{\circ} \mathrm{N}, 2.697714^{\circ} \mathrm{W}$ & 3-10 Aug. 2020 & 3 & 3 & & \\
\hline \multicolumn{8}{|c|}{ Site: Jabbeke } \\
\hline E & 0.19 & $51.1750513^{\circ} \mathrm{N}, 3.136943^{\circ} \mathrm{W}$ & 19-26 July 2021 & 4 & 9 & & \\
\hline
\end{tabular}


inside traps with nest material, these boxes had to be emptied every 1-2 days. Silverfish were collected to avoid double counting and traps were put back inside the mound. Between one and four traps were placed in and/or at the periphery of a nest at the same time (details of period of sampling and number of traps used are given in Table 2).

A maximum of 186 unique individuals was collected in nest A in 2020, 68 individuals were found in this nest in 2021. Nest A is located in a deciduous forest in Poperinge, Belgium (Table 2) at a forest edge along a road. Both adults and juvenile $L$. saccharinum were recorded, hinting that the life cycle can be completed in the nests. The nearest building is $156 \mathrm{~m}$ away. We also recorded in 2020 some individuals in three other F. rufa nests in the same forest complex in Poperinge (nest B: $N=4$, nest C: $N=1$, nest D: $N=3$ ). Apart from these records, no silverfish were collected in the 47 other $F$. rufa nests at this site. Surprisingly, we also found $L$. saccharinum in the nest of $F$. polyctena in another forest site (Jabbeke, Belgium) $44.3 \mathrm{~km}$ away from the Poperinge site (nest E: $N=9$, Table 2).

In a next step, we were interested to investigate how the ants interacted with the silverfish. Some arthropods associated with red wood ants provoke little or no aggression whereas others are heavily persecuted [18]. We brought some silverfish and F. rufa workers from nest A to the lab to conduct behavioral assays. We prepared a circular arena with a moist plaster bottom and with the walls coated with an anti-escape layer (Fluon). Ten ant workers were put into the arena and were able to acclimatize for 30 minutes. Then we introduced a silverfish, waited for $10 \mathrm{~s}$, and subsequently scored the aggression of the ants in the first twenty interactions with the silverfish. We replicated this with ten different silverfish individuals and replaced the workers for each trial.

Red wood ants responded very aggressively, $79.4 \%$ of the interactions were aggressive (biting, opening of the mandibles, chasing) on average, $8.9 \%$ of the interactions were biting (Fig. 1). The silverfish mostly tried to avoid contact with the red wood ants and ran away when detected. During the experiment, none of the tested silverfish were killed.

We recorded $L$. saccharinum in several outdoor ant nests. The very high abundances of the silverfish in nest $\mathrm{A}$ are especially intriguing. The presence of all stages over a three-year period indicated that a stable population has been established in the very hostile red wood ant environment. Although the red wood ants readily detected and attacked the silverfish, they may survive by hiding in the organic material, similar to some strongly attacked obligate ant associates $[19,20]$. The silverfish are likely attracted to the thermoregulated and humidity-controlled environment and the ample food resources. In that way, heated ant nests can serve as a stepping stone for thermophilous organisms to colonize other outdoor niches. It can be expected that $L$. saccharinum will increasingly explore outdoor habitats in temperate regions as an effect of global warming.

\section{Acknowledgements}

We are grateful for the sampling permission granted by the Agency of Nature and Forest (ANB) and by Karim Neirynck from Natuurpunt. This work was funded by Fonds Wetenschappelijk Onderzoek - FWO (Junior postdoctoral fellowship TP 1203020N) and the Fonds de la Recherche Scientifique - FNRS (Chargé de recherches TP 30257865).

\section{References}

[1] PARMEntier T. (2020). Guests of Social Insects. In: STARR C.K. (ed.) Encyclopaedia of Social Insects. Springer, Cham. https://doi.org/10.1007/978-3-319-90306-4_164-1 
[2] KADOChOVÁ Š. \& FrouZ J. (2014). Thermoregulation strategies in ants in comparison to other social insects, with a focus on red wood ants (Formica rufa group). F1000Research 2: 1-16. https://doi.org/10.12688/f1000research.2-280.v2

[3] JONES J.C. \& OldROYD B.P. (2006). Nest thermoregulation in social insects. Advances in Insect Physiology 33: 153-191. https://doi.org/10.1016/S0065-2806(06)33003-2

[4] Parmentier T., Dekoninck W. \& Wenseleers T. (2014). A highly diverse microcosm in a hostile world: A review on the associates of red wood ants (Formica rufa group). Insectes Sociaux 61: 229-237. https://doi.org/10.1007/s00040-014-0357-3

[5] Parmentier T., De Laender F. \& Bonte D. (2020). The topology and drivers of ant - symbiont networks across Europe. Biological Reviews 95: 1664-1688. https://doi.org/10.1111/brv.12634

[6] Rosengren R., Fortelius W., Lindström K. \& Luther A. (1987). Phenology and causation of nest heating and thermoregulation in red wood ants of the Formica rufa group studied in coniferous forest habitats in southern Finland. Annales Zoologici Fennici 24: 147-155

[7] LAAKSO J. \& SETÄLÄ H. (1997). Nest mounds of red wood ants (Formica aquilonia): hot spots for litter-dwelling earthworms. Oecologia 111: 565-569

[8] Molero-Baltanás R., Bach De Roca C., Tinaut A., Pérez J.D. \& Gaju-Ricart M. (2017). Symbiotic relationships between silverfish (Zygentoma: Lepismatidae, Nicoletiidae) and ants (Hymenoptera: Formicidae) in the Western Palaearctic. A quantitative analysis of data from Spain. Myrmecological News 24: 107-122. https://doi.org/10.25849/myrmecol.news_024:107

[9] Mendes L.F., VON BEEREN C. \& WitTE V. (2011). Malayatelura ponerophila - a new genus and species of silverfish (Zygentoma , Insecta) from Malaysia, living in Leptogenys army-ant colonies (Formicidae). Dtsch Entomol 58: 193-200. https://doi.org/10.1002/mmnd.201100023

[10] LocK K. (2007). Distribution of the Belgian Zygentoma. Notes fauniques de Gembloux 60: 25-27.

[11] Reyserhove L., Groom Q., Adriaens T., Desmet P., Dekoninck W., Van Keer K. \& Lock K. (2020). Ad hoc checklist of alien species in Belgium. Version 1.7. Research Institute for Nature and Forest (INBO). https://doi.org/10.15468/3pmlxs [accessed via GBIF.org, 17 January 2022].

[12] Parmentier T., Van Kerckvoorde M. \& Dekoninck W. (2013). First record of the myrmecophilous silverfish Atelura formicaria Heyden, 1855 in Belgium (Zygentoma: Nicoletiidae). Bulletin de la Société royale belge d'Entomologie/Bulletin van de Koninklijke Belgische Vereniging voor Entomologie 149: 27-28.

[13] MENDES L.F. (1988). Revisão do género Lepisma Lin., 1758 s.lat. (Zygentoma, Lepismatidae). Boletim da Sociedade Portuguesa de Entomologia (Suppl.) 2: 1-236.

[14] MENDES L.F. (1991). On the phylogeny of the genera of Lepismatidae (Insecta: Zygentoma). In: Veeresh G.K., Rajagopal D. \& Viraktamath C.A. (eds) Advances in Management and Conservation of Soil Fauna: 3-13. Oxford \& IBH, New Delhi, India.

[15] KAPLIN V. (2016). New Species of the bristletail families Ateluridae and Lepismatidae (Zygentoma) from Abkhazia and Adygea. Entomological Review 96 (7): 885-898. https://doi.org/10.1134/S0013873816070101

[16] Smith G. (2015). Australian Lepismatinae (Zygentoma: Lepismatidae). General \& Applied Entomology 43: 25-36.

[17] Parmentier T., Claus R., De Laender F. \& Bonte D. (2021). Moving apart together: comovement of a symbiont community and their ant host, and its importance for community assembly. Movement Ecology 9: 25. https://doi.org/10.1186/s40462-021-00259-5 
[18] Parmentier T, De Laender F, Wenseleers T \& Bonte D. (2018). Contrasting indirect effects of an ant host on prey - predator interactions of symbiotic arthropods. Oecologia 188: 1145-1153. https://doi.org/10.1007/s00442-018-4280-6

[19] Parmentier T., De Laender F., Wenseleers T. \& Bonte D. (2018). Prudent behavior rather than chemical deception enables a parasite to exploit its ant host. Behavioral Ecology 29: 12251233. https://doi.org/10.1093/beheco/ary134

[20] von Beeren C., Maruyama M., Hashim R. \& Witte V. (2010). Differential host defense against multiple parasites in ants. Evolutionary Ecolology 25 (2): 259-276. https://doi.org/10.1007/s10682-010-9420-3

[21] Molero Baltanás R., Gaju Ricart M. \& Bach de Roca C. (2014). Lepismas y libros: actualización del conocimiento sobre Lepisma saccharina (Zygentoma: Lepismatidae) en España. Boletín de la Sociedad Entomológica Aragonesa (S.E.A.) 54: 351-357.

[22] BLOCH D. (2007). Silverfish: a very old insect. (Silvurfiskur: Eitt elligamalt skordjór). Frøði 13: $30-31$.

[23] Mendes L.F. (2002). Tisanuros (Microcoryphia e Zygentoma: Insecta) de Portugal. Novos dados e consideraçóes. Comunicações des Instituo de Investigacao Cientifia tropical 3: 5-47.

[24] Molero-Baltanás R., Fanciulli P.P., Frati F., Carapelli A. \& Gaju-Ricart M. (2000). New data on the Zygentoma (Insecta, Apterygota) from Italy. Pedobiologia 44 (3-4): 320-332. https://doi.org/10.1078/S0031-4056(04)70052-9

[25] Mendes L.F., Gaju-Ricart M., Bach de Roca C. \& Molero-BaltanÁs R. (2000). New account on the thysanurans of the Azores (Insecta, Micocoryphia and Zygentoma) with description of a new species. Pedobiologia 44: 309-319. https://doi.org/10.1078/S0031-4056(04)70051-7

[26] HAZRA A.K., Biswas M. \& MitRA S.K. (1999). On some collections of Thysanura from East and North East India. Records of the Zoological Survey of India 97 (2): 29-38.

[27] Molero-Baltanás R., Gaju-Ricart M. \& Bach de Roca C. (1996). Los Lepismatidae antropófilos de España. Tomo Extraordinario. 125 Aniversario de la RSEHN: 178-181.

[28] Mendes L.F. (1995). A review of the Thysanura of Israel with new data on the Microcoryphia and Zygentoma. In: DeCu V., Nitzu E., Por F.D. \& Dimentman C.H. (eds) Soil Fauna of Israel: 87-110. Academiei Romane \& Israel Academy of Sciences and Humanities, Bucarest.

[29] Molero-Baltanás R., Gaju-Ricart M., Bach de Roca C. \& Mendes L.F. (1994). New faunistic data on the Lepismatidae of Spain (Apterygota, Zygentoma). Acta Zoologica Fennica, 195: 107-110.

[30] Mendes L.F., BACH DE Roca C. \& Gaju-RicART M. (1992). New data on the thysanurans fauna of the Canary islands. I. Zygentoma. Garcia de Orta, Séries Zoologia, Lisboa 16 (1-2): 195-203.

[31] Mendes L.F. (1992). Novos dados sobre tisanuros (Microcoryphia e Zygentoma) da América do Norte. Garcia de Orta, Séries Zoologia, Lisboa 16 (1-2): 171-193.

[32] Mendes L.F. (1989). Nouvelles données sur les Lepismatidae (Zygentoma) de l'Asie Orientale et de l'Indonésie. Garcia de Orta, Séries Zoologia, Lisboa 14(2): 79-92.

[33] Mendes L.F. (1985). On some thysanurons (Microcoryphia and Zygentoma: Apterygota) from Poland. Acta Zoologica Cracoviensia 30 (6): 215-220.

[34] Mendes L.F. (1984). The fauna of the Aegaean Island of Santorini. Part 7. Microcoryphia and Zygentoma, with additional records from other Greek localities. Stuttgarter Beiträge zur Naturkunde. Series A (Biologie) 372: 1-12. 
[35] Mendes L.F. (1983). New data on the Lepismatidae (Apterygota, Zygentoma) from the Cape Verde Islands. Andrias, Karlsruhe 3: 5-8.

[36] Mendes L.F. (1981). Nova nota sobre os Tisanuros (Apterygota, Microcoryphia e Zygentoma) da Europe e da Bacia Mediterrânica. Boletim da Sociedade Portuguesa de Entomologia 18: 1-9.

[37] Mendes L.F. (1980a). Note sur les Zygentoma (Insecta: Apterygota) de l'Europe et du Bassin Mediterranéen. Arquivos do Museu Bocage, Lisbon (2) 7: 215-260.

[38] Mendes L.F. (1980b). New data on the Thysanurons from Malta (Apterygota: Microcoryphia \& Zygentoma). Bollettino della Società Entomologica Italiana 112: 94-98.

[39] Mendes L.F. (1980c). Notes et descriptions sur quelques Thysanoures de l'Europe. Memorie della Società Entomologica Italiana 59: 3-33.

[40] Wygodzinsky P. (1970). Thysanura. In: BAsilewskyi P. (ed.) La Fauna Terrestre de l'Ile de Sainte Helene: 155-160. Annales Musée royal de l'Afrique Centrale. Série in Octavo. Sciences zoologiques 181 (3)

[41] WygODZINSKY P. (1967). On the geographical distribution of the South American Microcoryphia and Thysanura (Insecta). In: DeBoutTVille D. \& RAPOPORT E. (eds) Biologie de l'Amérique australe. Volume 3: 505-524. Centre National de la Recherche Scientifique, Paris.

[42] PACLT J. (1966). Neue Beiträge zur Kenntnis der Apterygoten-Sammlung des Zoologischen Staatsinstituts und Zoologischen Museums Hamburg. II. Lepismatidae und Maindroniidae. Entomologische Mitteilungen aus dem Zoologischen Museum Hamburg 57: 147-162.

[43] Wygodzinsky P. (1962). Neue Beiträge zur Kenntnis der Thysanura und Machilida Afghanistans. Opuscula Entomologica 27: 219-228.

[44] PACLT J. (1961). Borstenschwänze (Ins. Thysanura) des Senckenberg-Museums. Senckenbergiana Biologica 42: 75-84.

[45] WygODZINSKY P. (1959). Thysanura and Machilida of the Lesser Antilles and northern South America. Studies on the fauna of Curaçao and other Caribbean Islands 36: 28-49.

[46] Wygodzinsky P. (1958). Notes et descriptions de Machilida et Thysanura paléarctiques. Revue française d'Entomologie 25: 298-315.

[47] Wygodzinsky P. (1954). The Thysanura of the Netherlands (Apterygota, Insecta). I \& II. Natuurhistorisch Maandblad 43(10): 67-80.

[48] UCHIDA H. (1954). Apterygota of the Hachijô-Jima and its adjacent islands. Science Reports of the Faculty of Literature and Science of the Unviversity of Hirosaki 1 (1): 1-17.

[49] Wygodzinsky P. (1952). On some Machilidae and Lepismatidae from Israel, Cyprus and Arabia (Thysanura, Insecta). Bulletin of the Research Council of Israel 2: 260-263.

[50] SweETMAn H.L. (1944). Ecology of the Silverfish, Lepisma saccharina L. Bulletin of the Ecological Society of America 25 (3): 29

[51] Agrell I. (1944). Die schwedischen Thysanuren. Opuscula Entomologica 9: 23-26.

[52] Wygodzinsky P. (1941). Beiträge zur Kenntniss der Dipluren und Thysanuren der Schweiz. Denkschriften der Schweizerischen Naturforschenden Gesellschaft 74 (2): 111-227.

[53] StACH J. (1930). Apterygoten der aus dem nördlichen und östlichen Spanien gesammelt von Dr. F. Haas in den Jahren 1914-1919. Abhandlungen der Senckenbergischen Naturforschenden Gesellschaft 42: 3-83. 
[54] SтAсн J. (1929). Verzeichnis der Apterygogenea Ungarns. Annales Musei Nationalis Hungarici 26: $269-312$.

[55] Tillyard R. J. (1924). Primitive wingless insects. Part I. The silverfish, bristletails and their allies (Order Thysanura). New Zealand Journal of Science and Technology 7: 232-242.

[56] LinnANiemi W. (1912). Die Apterygotenfauna Finlands. II. Spezieller Teil. Acta Societatis Scientiarum Fennicae 40: 1-359.

[57] OudEMAns J.T. (1895). Systematische beschrijving der in Nederland voorkomende Thysanura. Tijdschrift voor Entomologie 38: 164-178.

[58] UzEL J. (1891). Šupinušky země české. Thysanura Bohemiae. Sitzugsberichte der Königlichen Böhmischen Gesellschaft der Wissenschaften, mathematisch-naturwissenschaftliche Classe 2: $3-82$.

[59] PARona C. (1882). Di alcuni Collembole e Thysanura raccolte dal Prof. P.M. Ferrari con cenno corologico della Collembola e Thysanura italianae. Annali del Museo civico di storia naturale di Genova 18: 453-464.

[60] BELKe G. (1866). Notice sur l'histoire naturelle du district de Radomysl (Gouvernement de Kief). Bulletin de la Société impériale des Naturalistes de Moscou 39 (3-4): 491-526.

[61] Contarini N. (1845). Cataloghi degli uccelli e degli insetti delle provincie di Padova e Venezia. Tipografia Baseggio edit., Bassano.

[62] Mohr N. (1786). Forsøg til en islandsk Naturhistorie, med adskillige oekonomiske samt andre anmoerkninger. Christian Friderik Holm, Køvenhavn.

[63] FÜSSLY J.C. (1775). Verzeichnis der ihm bekannten Schweitzerischen Inseckten. Steiner, Zürich \& Winterthur.

[64] Geoffroy M. (1762). Histoire abregée des insectes: qui se trouvent aux environs de Paris: dans laquelle ces animaux sont rangés suivant un ordre méthodique. Chez Durand, Paris.

[65] LinNAEUS C. (1758). Systema Naturae per regna tria naturae, secundum classes, ordines, genera, species, cum characteribus, diffentiis, synonymis, locis. Editio decima, reformata. Vol. Tom. $110^{\text {th }}$ Edn. Impensis Direct, Laurentii Salvii, Holmiae.

Manuscript received: 17 September 2021

Manuscript accepted: 24 January 2022

Published on: 3 February 2022

Branch editor: Kurt Jordaens 